\title{
Profile of nursing professionals on medical waste management
}

\author{
Perfil de profissionais de enfermagem no manejo dos resíduos dos serviços de saúde
}

\author{
Gisele Loise Dias ${ }^{1}$, Gianfábio Pimentel Franco ${ }^{2}$, Fernanda Sarturi³, Cleverson Antonio Ferreira Martins ${ }^{4}$ \\ ${ }^{1}$ Enfermeira .Pós-graduanda em Especialização em Educação Ambiental e Gestão da Organização Pública em Saúde. \\ ${ }^{2}$ Enfermeiro. Doutor em Ciências pela Universidade Federal de São Paulo. Docente do Curso de Graduação em Enfermagem da \\ UFSM-CESNORSa Maria (UFSM), campus de Palmeira das Missões/RS. \\ ${ }^{1}$ Enfermeira. Mestre em Enfermagem pela Universidade Federal de Santa Maria. Docente do Curso de Graduação em Enfermagem da \\ UFSM-CESNORS.Docente da Universidade Federal de Santa Maria (UFSM/RS), campus de Palmeira das Missões/RS. \\ Farmacêutico, mestrado em Ciências Farmacêuticas pela Universidade Federal do Paraná. Doutorando pela Universidade Federal
}

\section{Resumo}

O objetivo deste estudo foi analisar a conduta com relação à correta classificação dos RSS, dos profissionais de enfermagem atuantes em hospitais de duas cidades localizadas nas regiões norte e noroeste do estado do Rio Grande do Sul. Trata-se de um estudo exploratóriodescritivo e transversal sobre o manejo de resíduos de serviços de saúde (RSS). Constatou-se que os profissionais têm dificuldades para identificar e segregar os resíduos de acordo com a classificação proposta na RDC ANVISA $n^{\circ}$. 306/04. Este fato pode influenciar no momento do descarte, podendo aumentar os riscos à saúde do trabalhador, ao meio ambiente e ainda aumentar os custos hospitalares com o tratamento e a disposição final dos resíduos.

Palavras-chave: enfermagem, gerenciamento de resíduos, resíduos de serviços de saúde, meio ambiente, saúde pública.

\begin{abstract}
The aim of this study was to analyze the behavior with respect to the correct classification of medical waste of nurses working at hospitals in two cities located in the north and northwest of the state of Rio Grande do Sul (Brazil). This is an exploratory-descriptive and cross-sectional study on medical waste management (MWM). It was found that the nurses have difficulty in identifying and sorting the waste according to the classification proposed in the Resolution RDC no. 306/04. This fact may influence the time of disposal, which could increase the risks to workers' health and the environment, and also increase hospital costs for the treatment and disposal of waste.
\end{abstract}

Keywords: nursing, waste management, medical waste, environment, public health. 


\section{INTRODUCTION}

One of the concerns of society today is the final destination of solid waste. For a long time, the collection and disposal of solid waste apparently did not use to cause major problems because the garbage was deposited in distant regions. However, with increasing urbanization, it became more difficult to find suitable areas to absorb the expanding demand, and this issue gained visibility.

The inappropriate final destination of medical waste (MW) can harm public health, as it fosters the proliferation of infectious disease vectors. In addition, injury may occur by contamination of the environment and from the people directly involved in waste handling.

In Brazil, the resolution No. 306 of the Board (RDC) of the National Agency for Sanitary Surveillance (ANVISA) provides for medical waste management (BRASIL, 2004). Thus, according to this resolution, medical waste management is aimed at minimizing the production of such type of waste and providing a safe route, thus protecting health workers and preserving the environment. With regard to hospital management, depending on how the institution is structured and organized internally, professionals will have better or worse working conditions (OLINISK AND LACERDA, 2004). Thus, the way the institution deals with waste handling becomes very important to workers' health and the environment.

Reducing costs and product waste depends on training the subjects involved in this process (SISINNO AND MOREIRA, 2005). Therefore, the continuing education of such professionals is essential, as it influences the way they follow waste management procedures. Consequently, it is necessary to search for alternatives that can make the medical waste management system easier to operate and, thus, provide a safer workplace and lower environmental consequences.

This study is part of the "umbrella" project entitled Profile of undergraduate students and health professionals in the management of solid medical waste, and it aims at analyzing the behavior of Nursing students and health care professionals in hospitals as regards medical waste management at the units where they perform curricular activities.

\section{MATERIALS AND METHODS}

This research was conducted according to the regulations of the National Research Ethics Committee, in compliance with Resolution No. 196/96 of the National Health Council (BRASIL, 1996). The project was approved by the Research Ethics Committee of the Federal University of Santa Maria, technical report No. 20850. The subjects agreed to participate in the research and signed a consent form. During data analysis, the subjects were identified by numbers, and the survey was conducted in hospitals referred to as $A$ and $B$ to fulfill the ethical criterion of non-disclosure of names. A criterion for including the subjects in this study was employment at the respective hospital for more than three months. Data were collected by means of a questionnaire that covered basic questions about medical waste management. The design of the questionnaire was based on the current legislation on this issue (BRASIL, 2004). The questionnaire was administered to the participants in their actual workplace, and they were advised to fill it in when they were off-duty so as not to interfere with their activities.

The study is quantitative, descriptive/exploratory and cross-sectional. Descriptive/exploratory studies are conducted to collect detailed descriptions of the existing variables, and justify or evaluate current practices according to the data collected (LOBIONDO-WOOD AND HABER, 2001). Data analysis was performed by means of descriptive statistics. Thus, it was possible to calculate the averages and percentages of correct answers for each question. To calculate the percentage, the number of times that the 
answers appeared was counted, and then divided by the total number of subjects and multiplied by the number one hundred. In addition, tables were compiled for presentation of data. The software Epi-info was used for data analysis.

\section{RESULTS AND DISCUSSION}

The questionnaire was administered to 18 subjects at Hospital A (which had a total of 36 employees): ten nursing assistants; six nursing technicians and two licensed nurses. At Hospital B, the questionnaire was administered to 21 subjects (out of a total of 86 staff): 14 nursing technicians, three nursing assistants and four licensed nurses. Thus, a total of 39 subjects agreed to participate in the study. It should be noted that many of the subjects reported lack of time and/or reluctance to participate in the research, even though they were aware of the informed consent.

The socio-demographic questions of the questionnaire sought to identify the gender and age of the participants; $85 \%$ of subjects in the study were women and $15 \%$ were men. The average reported age was 36 years; the youngest subject was 20 years old and the oldest, 57 years old.

For the questions that specifically addressed waste management, the results showed that $72 \%$ of the subjects from Hospital A had received guidelines on the subject in their workplace. In contrast, $17 \%$ had never received guidelines, and for $11 \%$ of them, guidelines had been given partially during training. At Hospital B, $90 \%$ of the staff had received guidelines in the workplace, and $10 \%$ had never received guidelines.

As regards the final destination of medical waste, for $77 \%$ of the staff in Hospital A the correct treatment is given to each type of waste, and the other subjects said that the waste is incinerated $(6 \%)$ or disposed of in the open $(6 \%)$, whereas $11 \%$ did not know the answer (11\%). At Hospital B, $67 \%$ of the staff answered that each type of waste receives the correct treatment, and $14 \%$ of them said that medical waste is incinerated, while $19 \%$ of them did not know the destination.
With respect to classification, at Hospital A 39\% said they were aware of proper waste sorting procedures. The same percentage of respondents $(39 \%)$ reported partial knowledge of medical waste classification, and $22 \%$ were unaware of such classification. At Hospital B, $43 \%$ of the respondents were aware of waste classification; 39\% reported partial knowledge; $14 \%$ reported lack of knowledge of the classification, and 5\% did not answer the question. Below are the results for the composition of medical waste groups. These are classified as follows (BRASIL, 2004):

- Group A - Infectious Waste;

- Group B - Chemical Waste;

- Group C - Radioactive Waste;

- Group D - Common Waste;

- Group E - Waste sharps.

Questions about Groups A and E are presented sequentially, because these groups represent the amount of medical waste considered to be infectious (BRASIL, 2004).

Questions about the composition of Group A, according to the current legislation (BRASIL, 2004), had the following result: at Hospital A, $66 \%$ of the respondents were unaware of the classification of Group A, while $11 \%$ answered correctly and $23 \%$ gave incorrect answers. At Hospital B, 52\% knew the correct composition, $24 \%$ were unaware of the classification and the same percentage (24\%) answered incorrectly.

For the composition of Group E, at Hospital A, 16\% answered correctly, 18\% gave incorrect answers, and $66 \%$ reported that they were unaware of the classification. At Hospital B, $71 \%$ answered correctly and $29 \%$ were unaware of the classification.

Groups B, C and D correspond to noninfectious waste or waste whose final destination was different because of composition (e.g., chemical, radioactive or common waste) (BRASIL, 2004).

As for Group B, $66 \%$ of the respondents at Hospital A reported lack of knowledge of the classification; $11 \%$ answered correctly and $23 \%$ gave incorrect answers. At Hospital B, 
$71 \%$ gave correct answers, and $29 \%$ said they were unaware of the classification.

As for Group C, $89 \%$ of the staff at Hospital A answered incorrectly, with $61 \%$ of respondents reporting that Group C consists of leftovers. Only $11 \%$ knew the correct composition of the group. At Hospital B, 71\% answered correctly and $24 \%$ answered that they were unaware of the classification of the group.

About the composition of Group D, $66 \%$ of the respondents at Hospital A reported that they were unaware of the classification of the group, and $11 \%$ gave correct answers. At Hospital B, 71\% answered correctly, and 29\% reported not knowing the classification of the group. Table I briefly presents the percentage of correct answers for questions about the composition of the groups. Tables II and III show details about the incorrect responses of staff from Hospital A and B, respectively.

Table I - Percentage of correct answers to the questions about waste group composition, according to Resolution RDC no. 306.

\begin{tabular}{ccc} 
& Hospital A & Hospital B \\
\hline Group A & $11 \%$ & $52 \%$ \\
\hline Group B & $11 \%$ & $71 \%$ \\
\hline Group C & $11 \%$ & $71 \%$ \\
\hline Group D & $11 \%$ & $71 \%$ \\
\hline Group E & $17 \%$ & $71 \%$ \\
\hline Average & $12 \%$ & $68 \%$
\end{tabular}

Table II - Distribution of incorrect answers about waste group composition for Hospital A. Palmeira das Missões, 2013.

\begin{tabular}{ccccccc} 
Group & A & B & C & D & E & $\begin{array}{c}\text { Do } \\
\text { not } \\
\text { know }\end{array}$ \\
\hline A & - & $11 \%$ & $6 \%$ & $6 \%$ & $0 \%$ & $67 \%$ \\
\hline B & $6 \%$ & - & $11 \%$ & $6 \%$ & $0 \%$ & $67 \%$ \\
\hline C & $6 \%$ & $0 \%$ & - & $61 \%$ & $22 \%$ & $0 \%$ \\
\hline D & $17 \%$ & $6 \%$ & $0 \%$ & - & $0 \%$ & $67 \%$ \\
\hline E & $6 \%$ & $6 \%$ & $0 \%$ & $6 \%$ & - & $67 \%$
\end{tabular}

Table III - Distribution of incorrect answers about waste group composition for Hospital B. Palmeira das Missões, 2013.

\begin{tabular}{lllllll} 
Group & A & B & C & D & E & $\begin{array}{l}\text { Do } \\
\text { not } \\
\text { know }\end{array}$ \\
\hline A & - & $14 \%$ & $5 \%$ & $5 \%$ & $0 \%$ & $24 \%$ \\
\hline B & $0 \%$ & - & $0 \%$ & $0 \%$ & $0 \%$ & $29 \%$ \\
\hline C & $0 \%$ & $5 \%$ & - & $0 \%$ & $0 \%$ & $24 \%$ \\
\hline D & $0 \%$ & $0 \%$ & $0 \%$ & - & $0 \%$ & $29 \%$ \\
\hline E & $0 \%$ & $0 \%$ & $0 \%$ & $0 \%$ & - & $29 \%$
\end{tabular}

The staff also answered questions about the stages of the medical waste management plan (MWMP). At Hospital A, 44\% gave correct answers, $28 \%$ were unaware of the steps of the MWMP, and $28 \%$ answered incorrectly. At Hospital B, $62 \%$ gave correct answers, $24 \%$ reported not knowing the steps of the plan and $14 \%$ answered incorrectly.

Based on the results, it was observed that providing guidelines on medical waste is essential for all the stages of management. By means of the correct sorting at the time of generation, medical waste is sent for safe and appropriate disposal, thus avoiding misuse of treatment resources. To achieve these goals, initial and ongoing staff training is of paramount importance (KURCGANT, 2005). Staff training is crucial to reduce 
environmental impacts and ensure the health of the staff; in addition, it is a part of proper medical waste management (REZENDE, 2006).

As regards the final destination, a great deal of doubt about this step was observed. Health workers who are aware of the final destination tend to sort waste properly at the time of generation, because they believe that the decharacterization processes are different for each group. For example, for infectious waste (Groups A and E), there are different ways, such as autoclaving, microwaving, incineration and pyrolysis (ELEUTERIO AND HAMADA AND, PADIM, 2008). Among the abovementioned treatments, the most frequently used are autoclaving and incineration. However, these two processes have positive and negative aspects. Autoclaving has great efficiency, but it does not reduce the volume of waste generated. Besides, after the treatment, the waste may produce manure at the disposal site even though it is disinfected because its constitution was not changed, only its pathogenicity (ELEUTERIO AND HAMADA AND, PADIM, 2008). Incineration should keep strict control of greenhouse gas emissions, although this technique can be used for any type of infectious waste. In addition, it reduces the weight and volume of waste significantly (DIAS ET AL. 2009). Solid waste from Group $B$, when not treated, must be placed in hazardous waste landfills (Class I). When found in the liquid form, this type of waste must undergo specific decharacterization treatment before the final destination (BRASIL, 2004).

Waste from Group C should strictly follow the standards of the National Commission of Nuclear Energy (CNEN) (CNEN, 1985), because this waste must remain stored until its radioactivity decay; later, it must be sent to a hazardous waste landfill (Class I) (BRASIL, 2004). Waste from Group D is sent to a common landfill, but there is a large amount of such waste that can be sorted - the recyclables. These, in some cases, can be donated or sold to cooperatives, and the income generated can be reversed to the hospital itself. The recycling of materials is important because, in addition to reducing the extraction of natural resources for manufacturing, reduces energy consumption, as well as the accumulation of waste (SILVA; RAMPELOTTO; 2012).

Even though most health workers had stated that they had knowledge of medical waste classification, their answers to the questionnaire showed that there is some doubt about this. For example, at Hospital B, although the majority of the respondents had correctly answered the questions about the composition of the groups, approximately $5 \%$ of them confused the composition of groups $\mathrm{C}$ and $\mathrm{D}$.

The situation was worse at Hospital A, where it was observed that the majority is unaware of the composition of waste groups. This fact tends to adversely affect waste management, because waste sorting can be impaired if the staff do not know the composition of the groups.

For the question about the steps of medical waste management, it was observed that most of the respondents recognized the steps correctly. These steps are: segregation, containerization, labeling, on-site storage, intermediate storage, on-site treatment, off-site storage, collection and off-site transport, treatment and disposal (BRASIL, 2004). However, it was identified that there is still doubt about these stages, both at Hospital A $(28 \%)$ and at Hospital B (14\%). Such doubt may be due to the staff's lack of access to the MWMP, whose preparation requires the description of these stages (BRASIL, 2004).

\section{CONCLUSION}

The development of this research and its results showed that the respondents of the questionnaire have difficulty in identifying and classifying medical waste. As a result, they may fail to manage waste as mandated by the current legislation. For this reason, it is suggested that health institutions should provide conditions for professionals to easily sort waste into groups at the time of generation. One way to help the staff to do so is to label the waste bins with the particular 
waste groups. In addition, continuing education workshops, group games focused on this theme and extension courses (taught by the Federal University) are alternatives that can raise awareness and aid the work of health professionals, provided that the cooperation of all those involved in environmental issues takes place (BURG, AND SILVEIRA, 2008). It should be stressed that it is not enough for the hospital staff to be able to sort infectious and non-infectious waste only, because there are other types of waste that do not fall into this classification; for example, chemical residues such as mercury resulting from breakage of a thermometer and expired drugs, or radioactive materials, which cannot be simply disposed of as contaminated materials, because these residues require special treatment before final disposal. Therefore, it should be noted that the inadequate management of medical waste can increase treatment and disposal costs, have an impact on workers' safety and generate environmental damage.

\section{REFERENCES}

BRASIL, MINISTÉRIO DA SAÚDE. Resolução RDC N $N^{\circ}$ 306, DE 7 DE DEZEMBRO DE 2004. Dispõe sobre o Regulamento Técnico para o gerenciamento de resíduos de serviços de saúde e dá outras providencias. Brasília, 2004. Available from:

<http://www4.anvisa.gov.br/base/visadoc/CP/ CP\%5B20735-1-0\%5D.pdf $>$. Access on 2013 MAY. 10

OLINISKI S.R; LACERDA M.R. As diferentes faces do ambiente de trabalho em saúde. Cogitare Enferm. ;9(2):43-52, 2004.

SISINNO C.L.S; MOREIRA J.C. Ecoeficiência: um instrumento para a redução da geração de resíduos e desperdícios em estabelecimentos de saúde. Cad. Saúde Pública, Rio de Janeiro, v. 21, n. 6, Dec. $2005 . \quad$ Available from $<$ http://www.scielo.br/scielo.php?script=sci artt ext\&pid $=$ S0102311X2005000600039\&lng $=$ en\&nrm $=$ iso $\quad>$. Access on 2013 Apr. 15.
BRASIL, MINISTÉRIO DA SAÚDE. Resolução 196/96 do Conselho Nacional de Saúde/MS Sobre Diretrizes e Normas Regulamentadoras de Pesquisa envolvendo seres humanos. Diário Oficial da União, 10 de outubro de 1996. Available from: $<$ http://ppgl.unb.br/site/images/arquivos/Resol ucao196-96.pdf $>$. Access on 2013 MAY. 10.

LOBIONDO-WOOD G, HABER J. Pesquisa em enfermagem: métodos, avaliação, crítica e utilização. 4 ed Rio de Janeiro: Guanabara Koogan, 2001.

KURCGANT P. Gerenciamento em enfermagem. Rio de Janeiro: Guanabara; Koogan; 2005.

REZENDE L.R. Vulnerabilidade dos geradores de resíduos de saúde frente às resoluções $n .358$ Conama e RDC n. 306 Anvisa. O Mundo da Saúde.; 2.ed.; 1-10; 2006.

ELEUTÉRIO J.P.L; HAMADA J; PADIM A.F, 2008. Gerenciamento eficaz no tratamento dos Resíduos de Serviços de Saúde - estudo de duas tecnologias. XXVIII Encontro Nacional de Engenharia de Produção - Enegep, Rio de Janeiro: Available from: $<$ http://www.abepro.org.br/biblioteca/enegep20 08_TN_STP_069_490_11445.pdf >. Access on 2013 MAY.25.

DIAS L.M.A; FARIA R.C; CARVALHO T.A.H; LEITE M.P.B.A; OLIVEIRA. F.S. Incineração de resíduos de serviço de saúde-lixo hospitalar: uma oportunidade de receita para o hospital escola de Itajubá. VI Simpósio de Excelência em Gestão e Tecnologia-SEGeT. Resende-RJ, 2009. Available from: $<$ http://www.aedb.br/seget/artigos09/274 274 Artigo_Seget.pdf.> Access on 2013 JUN.03.

COMISSÃO NACIONAL DE ENERGIA NUCLEAR. Gerência de rejeitos radioativos em instalações radioativas. Rio de Janeiro: CNEN, 1985. Available from: <http://www.cnen.gov.br/seguranca/normas/m ostra-norma.asp?op $=605>$. Access on $2013 \mathrm{Jul}$. 29. 
SILVA, N.M.; RAMPELOTTO E.M. Segregação dos resíduos sólidos hospitalares. Revista de Monografias Ambientais. Santa Maria, vol.(5), n5, p. $1174-1183$, 2012. ISSN: $2236-1308$.

BURG, G; SILVEIRA, D.D. Proposal of an environmental management model for Nephrology services. Acta paul. enferm. [online]. 2008, vol.21, pp. 192-197. Available from: $<$ http://www.scielo.br/scielo.php?script=sci artt ext\&pid=S0103-

$\underline{21002008000500010 \& \operatorname{lng}=e n \& n r m=i}>$. Access on 2012 Jul. 17. 